\title{
Analysis of Water Quality in Historical Shipwreck Sites to Support the Development of Marine Ecotourism in the Thousand Islands
}

\author{
Agustin Rustam ${ }^{1 *}$, Ira Dillenia ${ }^{1}$, Rainer A Troa ${ }^{1}$, Eko Triarso ${ }^{1,}$ Ofri Johan ${ }^{2}$, Nur Azmi Ratna Setyawidati ${ }^{1,}$ LPA Savitri \\ CH Kusuma ${ }^{1}$, Shinatria Adhityatama ${ }^{3,4}$
}

${ }^{1}$ Marine Research Centre, Ministry for Marine Affairs and Fisheries, Republic of Indonesia

${ }^{2}$ Research Institute for Ornamental Fish Culture, Ministry for Marine Affairs and Fisheries, Republic of Indonesia

${ }^{3}$ The National Research Center for Archaeology, Ministry of Education, Culture Research and Technology

${ }^{4}$ Griffith Center for Social and Cultural Research Griffith University, Gold Coast, Queensland, Australia

\begin{abstract}
Thousand Islands has become the main focus of the marine tourism development in Special Capitol Region of Jakarta (DKI Jakarta). In this regard, one of the marine tourism objects proposed to be further developed is historical shipwreck diving as a new marine ecotourism attraction in the Thousand Islands. The historical sites of shipwrecks that are widely scattered underwater are expected to give added value to the beauty of underwater panorama because most of the sites have been covered with coral reefs adding to the uniqueness to the underwater diving attractions. However, the high activity on the North Coast of Java area and surrounding islands tends to affect the water quality and the presence of shipwrecks assuming it will be used for the development of diving tourism. This study aims to determine the carrying capacity of water quality on shipwrecks based on in situ water quality measurement and image analysis. The method of data collection and analysis carried out is a combination of in situ measurements at the location; analysis of water samples with laboratory testing and analysis of Landsat 8 satellite imagery. The result showed that nutrient and orthophosphate values of nitrate, which supported the life of marine biota and micro-algae that helped the biota's biofouling process, increased the site's attractiveness from $0.094-0.101 \mathrm{mg} / \mathrm{L}$ and $0.005-0.008 \mathrm{mg} / \mathrm{L}$, respectively. Furthermore, other water quality values measured are still in accordance with quality standards for marine life survival on shipwrecks and ecotourism, especially dive spots with clear water visibility.
\end{abstract}

\section{Introduction}

Geographically, the Thousand Islands Administrative District is stretched from Jakarta Bay to the northernmost boundary, Sebira Island. The total distance of the outer islands from Jakarta coastline is 100 nautical miles. This district possesses an area approximately 11 times the Jakarta land area, with a total of 110 islands. Furthermore, the sources of complete ecosystem wealth in the Thousand Islands include coral reef, seagrass, and mangrove ecosystems. The beauty of the coral reef coastal ecosystem makes the Thousand Islands one of the 10 priority national tourism destinations and one of the 30 leading marine tourism [1]. The beauty of the shallow waters forms and constitutes the Thousand Islands collection which has 134 types of coral reefs, seagrass, and mangrove ecosystems with white sand beaches. It also possesses 38 sunken ships scattered around the Island of Pari, Pramuka, Tidung, Papatheo to Sabira, at the northern tip of the Thousand Islands [2].

However, the existence of the Thousand Islands as the tourism destination threatens the shipwreck sites and the beauty of its waters and coral reefs. Moreover, Jakarta Bay as the estuary of 16 major rivers such as the
Ciliwung and Citarum Rivers carries waste from the mainland. Waste that accumulates in river mouths are transported far away by ocean currents, thereby threatening ecosystems and cultural heritage sites in the Thousand Islands. The threats to the site of a sunken ship or shipwreck are determined by uncovering the dynamics that affect water quality, coastal ecosystems, and fishery production. This effect can be positive, as the existence of shipwrecks can become artificial reefs or FADs for various types of fish as well as become a diving tourist area such as in Tulamben, Bali. Meanwhile, the negative effects that occur includes the decreased water quality due to the dissolution of hazardous materials from the site, and remnants from the ship structure itself. Therefore, an initial study on the water quality condition at the site of the shipwreck is important. The common parameters are temperature, salinity, $\mathrm{pH}$, brightness, and some nutrients such as nitrogen (nitrate, nitrite, and ammonia), phosphate, and DO. The purpose of this study was to determine the carrying capacity of water quality on shipwrecks based on data analysis of several water quality parameters.

\section{Methods}

\footnotetext{
* Corresponding author: aqustin.rustam@kkp.qo.id
} 
The data collection methods used were carried out by in situ measurements at the location and the analysis of water samples by testing in the laboratory. The parameters measured in situ include Temperature, $\mathrm{pH}$, Dissolved Oxygen (DO), Salinity, and Electrical Conductivity. These measurements were conducted using portable instruments, such as a $\mathrm{pH}$ meter to measure $\mathrm{pH}$, a DO meter to measure dissolved oxygen levels, and an SCT meter to measure salinity values and electrical conductivity. Meanwhile, temperature measurement data were collected from any one of the three instruments, because each has a temperature sensor that shows air temperature. All of the tools mentioned above had a relatively similar operating method, by immersing a probe-shaped sensor directly into the liquid object to be measured. The results were shown on the display instrument with units of $\mathrm{pH}$ for measuring $\mathrm{pH}, \mathrm{mg} / \mathrm{L}$ for measuring dissolved oxygen levels, \%o (per mille) for salinity values, $\mathrm{mS} / \mathrm{cm}$, or $\mu \mathrm{S} / \mathrm{cm}$ for conductivity values, and ${ }^{\circ} \mathrm{C}$ for temperature.

In measuring water at sea level, the probe sensor tool can be directly lowered into the water until the entire probe is submerged. This method can be carried out as long as its cable length reaches the depth of the measurement point. Meanwhile, to measure water from a depth that exceeds the probe cable length, the first step is to take obtain water from the desired depth using a Van Dorn water sampler. In this survey, a van dorn was used to collect water from a depth of 20 meters from the water surface. Subsequently, the van dorn device was removed vertically, and the cover in the upper position opened. The probe from the instrument was then inserted into the van dorn apparatus and closed again with the cover until the reading of the measuring instrument was completed. This technique was carried out as a step to preserve the original condition of the air taken from a depth.

The parameters tested in the laboratory include nitrate $\left(\mathrm{NO}_{3}-\mathrm{N}\right)$ and dissolved phosphate (Ortho Phosphate-P) parameters. The measurement parameters were carried out on air samples taken from a depth of 20 meters. After the in situ measurement process was completed, the water in the van dorn was placed in an HDPE bottle container. Sample preservation was then carried out by adding $\mathrm{H}_{2} \mathrm{SO}_{4}$ to obtain a $\mathrm{pH}<2$, subsequently testing was performed in the laboratory. Furthermore, nitrate parameter testing was carried out using the cadmium reduction method which refers to APHA 4500- $\mathrm{NO}_{3}$-E. The dissolved phosphate parameters were measured using the ascorbic acid method which refers to APHA 4500-P E.

\subsection{Image Analysis}

Satellite Data:

Landsat 8 Satellite Imagery OLI TIRS

Acquisition period :

2015-June-01st to 2020-June-30 ${ }^{\text {th }}$

Software:

Earth Engine and ER Mapper.

Acquisition Area:
Waters around the Thousand Islands, coordinate area $5^{\circ} 08^{\prime} 46.88^{\prime \prime}$ - $6^{\circ} 06^{\prime} 01.07^{\prime \prime}$ South Latitude and $106^{\circ} 18^{\prime} 35,35^{\prime \prime}-107^{\circ} 06^{\prime} 26,88^{\prime \prime}$ East Longitude.

The Area of Interest data extraction is shown as follows:

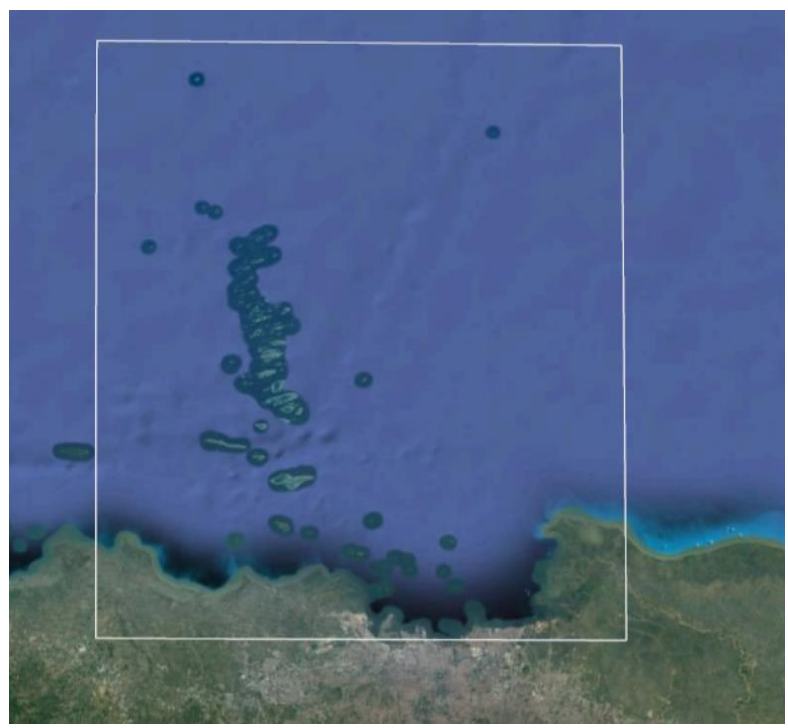

Figure 1. Thousand Islands data extraction area (Image data processing, 2020)

\section{Results and Discussion}

From the 38 shipwreck sites potency in Northtern Jakarta Waters, 8 shipwrecks were discovered in the Thousand Islands by field survey of the research. The existence of these shipwrecks may be caused by the density of shipping lanes, conditions of weather, ship and water bathymetry. The shipwreck is known to contain history which can be used as marine tourism destinations besides the beauty of coral such as in Tulamben, Bali. The shipwrecks include the Sebira, the Papatheo, the Dutch, the Tugboat, the Poso, the Tabularasa, the Tidung, and the Shinta wreck. The in situ water quality study focused on the three shipwreck locations of the Papatheo, the Tabularasa, and the Poso. Another study was based on analysis of Landsat imagery for the Thousand Islands area (see: Fig. 2).

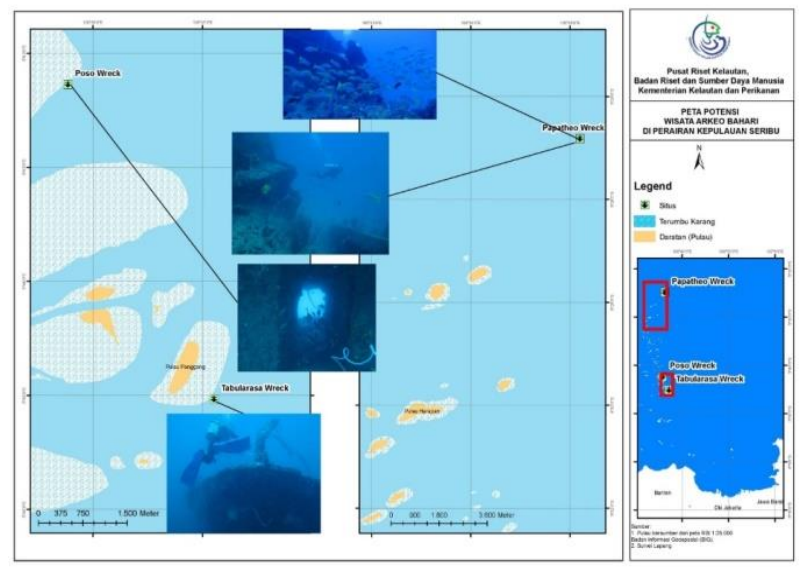

Figure. 2. The study area of the shipwreck as a marine archeology tourism potential in the Thousand Islands Waters 


\subsection{Sea Surface Temperature}

This sea surface temperature model was processed using the algorithm method carried out in the study is as follows [2]:

$$
\operatorname{SST}=-0.0054 \times 3+0.2166 \times 2-2.9425 \mathrm{x}+43.461
$$

(1)

The processing results showed that the sea temperature in the study area feel within the range of $24-29^{\circ} \mathrm{C}$.

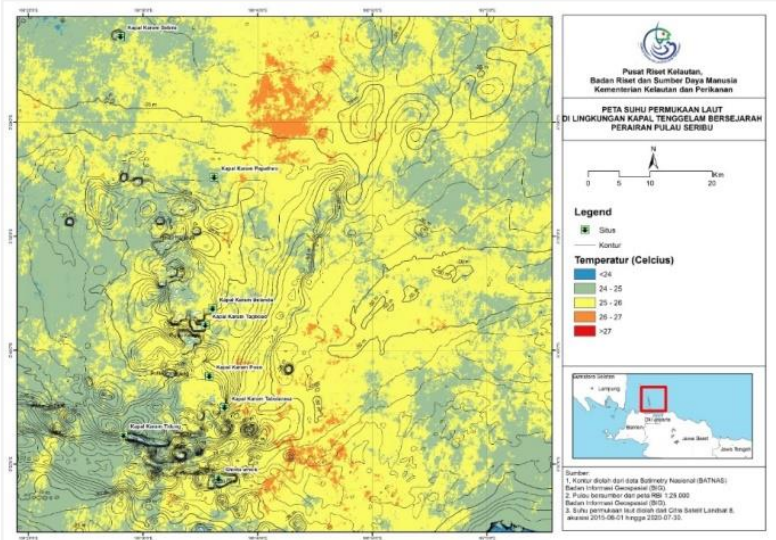

Figure. 3. Distribution map of the Thousand Islands sea surface temperature (Image data analysis, 2020).

Based on image analysis, the spatial distribution of surface temperature was within $24-29^{\circ} \mathrm{C}$, especially in the location of the shipwreck. Based on [3] for marine life and tourism, this value is still within the range of quality standards. These standards are a natural temperature with an upper threshold for coral reefs and seagrass of $30^{\circ} \mathrm{C}$ with an increase of $<2^{\circ} \mathrm{C}$. The in situ measurement results of sea surface temperature at the study site were higher than the ones from the image analysis, which was within the range of $30.1-31.6{ }^{\circ} \mathrm{C}$. Furthermore, the high temperature was occurred because the measurement time was during the day and the temperature increase was still below the tolerance limit of $<2{ }^{\circ} \mathrm{C}$.

\subsection{Water Clarity}

The image analysis of water clarity of the Thousand Islands, ranged spatially from $1-2 \mathrm{~m}$, except for the brightness on the coast of small islands, which ranges from $0-4 \mathrm{~m}$. The farthest study location from the mainland of Jakarta Bay was the Papatheo wreck with a brightness of $1-2 \mathrm{~m}$. Meanwhile, the location of Poso and Tabularasa wreck was $2-4 \mathrm{~m}$. This indicates that there is still influence from the mainland where Jakarta Bay is the river mouth of 16 major rivers. Therefore, there are influences of sedimentation carried by the river to the location, as well as from the activities on small islands closest to the shipwreck.

Overall, the brightness value was still good and appropriate with the quality standards of seawater for both marine tourism and marine life, especially corals. The measured physical parameters related to the visibility of the waters throughout the observation locations are clear. Water visibility is one of the important parameters in marine tourism, especially in diving, to enjoy the beauty of the underwater world, such as coral reefs, and the Papatheo, Poso, and Tabularasa shipwrecks. Moreover, clear visibility is closely related to the growth of coral reefs which require sunlight for zooxanthellae (algae) photosynthesis. This is very important for the symbiotic process of mutualism with coral animals, which enables them to form reefs (see: Fig. 2).

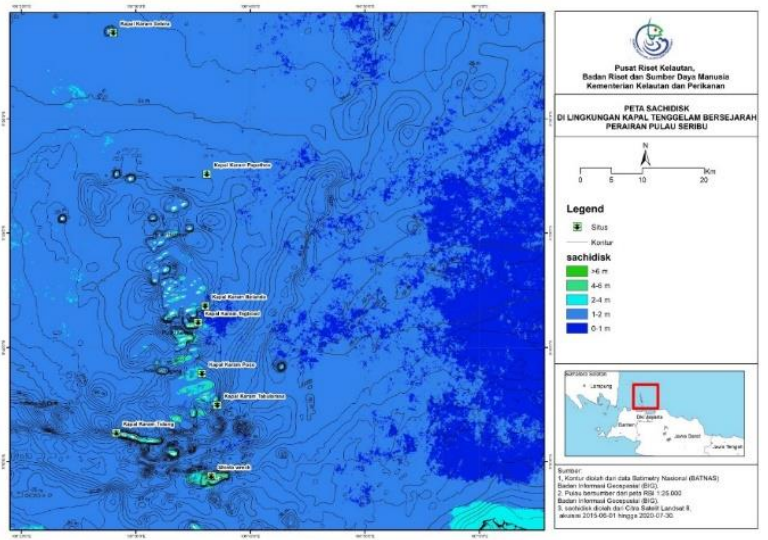

Figure 4. Distribution map of the water clarity of the Thousand Islands (Image data analysis, 2020)

The conductivity of seawater in the study area ranged from 50.11 to $51.28 \mu \mathrm{s} / \mathrm{cm}$, with an average of $50.80 \pm 0.4 \mu \mathrm{s} / \mathrm{cm}$. This value is very low compared to the natural conductivity of seawater at a temperature of $30^{\circ} \mathrm{C}$ and a salinity of $27 \mathrm{PSU}$, which is in the range of $46300-47800 \mu \mathrm{s} / \mathrm{cm}$. Therefore, it is concluded that the presence of shipwrecks does not affect the conductivity of the waters. It is also observed in the in situ measurements results, that the measured conductivity is a normal value for seawater.

\subsection{Salinity}

The salinity value image analysis was based on the Cimandiri algorithm [4]. The algorithm use as follows:

$$
\begin{aligned}
\text { Salinity }= & 29,983+165,047(\mathrm{~B} 4)-260,227(\mathrm{~B} 3)+ \\
& 2,609(\mathrm{~B} 2)
\end{aligned}
$$

The salinity value extracted from the Landsat 8 satellite in the study area ranged from $20-31$ PSU.

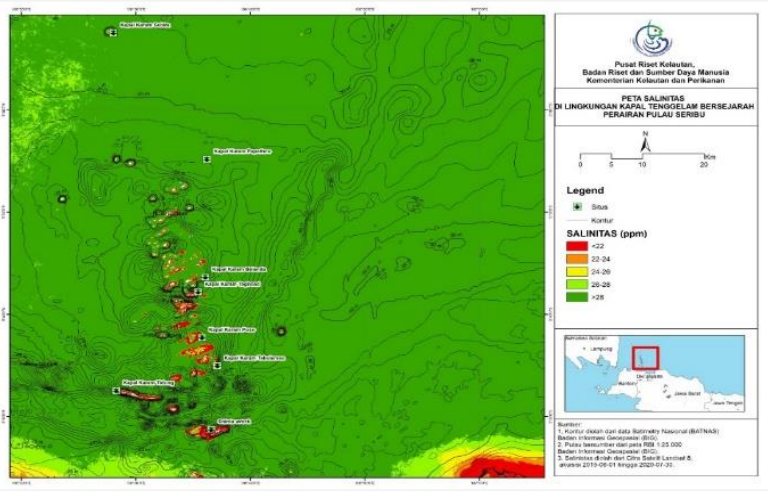

Figure 5. Map of the Thousand Islands salinity spatial distribution (Image data analysis, 2020) 
The distribution of salinity in the Thousand Islands specifically ranged from 22 - 28 PSU, with low salinity values near the mainland, both small islands, and the mainland coast of the Jakarta Bay (see: Fig. 5). The measurements results of salinity distribution at the Papatheo, Poso, and Tabularasa shipwreck locations ranged from 32.93 - 33.94 PSU with an average of $33.4 \pm 0.33$ PSU. Moreover, salinity measurements directly at the shipwreck location showed that the natural salinity of the seawater was suitable for marine life. This salinity was correlated with [3] for corals ranging from 33 -34 PSU with a change of $<5 \%$ from the average seasonal salinity.

\section{4 pH Value at the Research Site}

The value of the $\mathrm{pH}$ concentration at the study site ranged from 7.82 to 8.11 with an average of $7.98 \pm 0.08$, which is the given $\mathrm{pH}$ of seawater. The $\mathrm{pH}$ value in the waters was influenced by several factors including biological activity, photosynthesis, temperature, oxygen content, and the presence of cations and anions. Moreover, changes in $\mathrm{pH}$ values can also be caused by industrial and household waste carried by rivers [4] with river $\mathrm{pH}$ values generally low $(<7)$ therefore the presence of ions and cations in water is also low. The $\mathrm{pH}$ value at the study site based on[3] was still suitable for marine life and marine tourism (7-8.5).

\subsection{Dissolved Oxygen}

The analysis of the oxygen solubility value in the image involved the empirical approach of Alekin [5]based on the measured water temperature and salinity data. The algorithm is as follows:

$\mathrm{O}_{2}(\mathrm{mg} / \mathrm{l})=14.161-0.3943 \mathrm{t}+0.00714 \mathrm{t} 2-$ $0.0000646 \mathrm{t} 3-\mathrm{S}(0.0841-0.00256 \mathrm{t}+0.0000374 \mathrm{t} 2)$ (3)

Information:

$\mathrm{t}=$ temperature $\left({ }^{\circ} \mathrm{C}\right)$,

$\mathrm{S}=$ salinity

Dissolved oxygen is one of the important parameters related to the presence of marine biotas such as fish, seagrass, coral reefs, and plankton. Based on the [3] quality standard no. 51 of 2004 appendix III, the DO value which supports the life of biota and marine tourism is $>5 \mathrm{mg} / \mathrm{L}$. Moreover, the DO also indicates whether waters are polluted or not as well as the level of fertility. Lee et al, (1978) [6] classified DO values into four groups, include uncontaminated $(>6.5 \mathrm{mg} / \mathrm{L})$, low polluted $(4.5-6.5 \mathrm{mg} / \mathrm{L})$, moderate polluted $(2.0-4.5$ $\mathrm{mg} / \mathrm{L})$ and high polluted $(<2.0 \mathrm{mg} / \mathrm{L})$. The spatial distribution of DO showed uniform values with higher values approaching the land. The results of the image analysis showed the DO values ranged from 6.25 to over $6.75 \mathrm{mg} / \mathrm{L}$. The results of in situ measurements at three shipwreck locations in Papatheo, Poso, and Tabularasa shipwrecks, the DO values ranged from 4.7 to $5.8 \mathrm{mg} / \mathrm{L}$ with an average of $5.14 \pm 0.57 \mathrm{mg} / \mathrm{L}$. This value correlated with the [3]

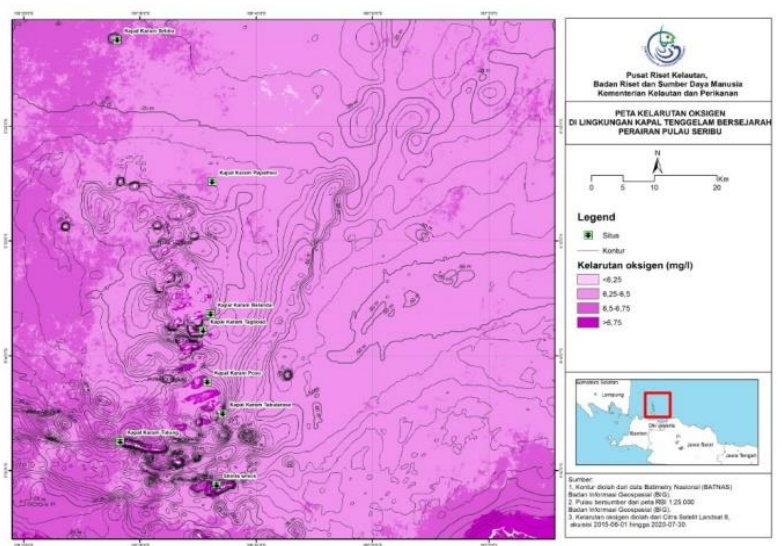

Figure 6. Distribution map of dissolved oxygen in the Thousand Islands (Image data analysis, 2020)

\subsection{Nutrients (Nitrates and Orthophosphates)}

Nutrient analysis was carried out in situ only at the study site where the shipwreck was located. Nutrient values for nitrate ranged from $0.094-0.101 \mathrm{mg} / \mathrm{L}$ and orthophosphate $0.005-0.008 \mathrm{mg} / \mathrm{L}$. The importance of conducting a nutrient analysis was related to the presence of biota growing near shipwrecks which include coral reefs. Moreover, nitrate and phosphate are some of the nutrient parameters closely related to water fertility. Nitrate is one of the chemical compounds that can be utilized by plants, is stable, easily soluble in water, and derived from the nitrification process of ammonia [7]. Meanwhile, phosphate originates from phosphorus which is reactive in water and plays an important role in the growth and metabolism of marine biota such as phytoplankton besides other elements $[4,5,8]$. Based on [3], the value of nitrate exceeds the quality standard and phosphate is still below the quality standard. Therefore, it is suitable for marine life (aquaculture) and marine tourism.

\subsection{Mapping Shallow Sea Bottom Habitats}

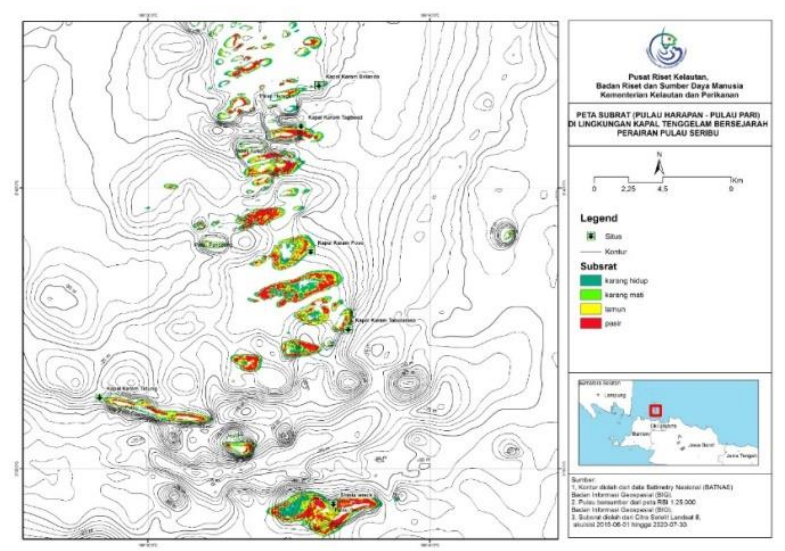

Figure. 7. Distribution map of the bottom substrate of the Thousand Islands waters (Image data analysis, 2020). 
Image analysis related to the distribution of the substrates includes the distribution identification of sand, seagrass, live coral, and dead coral according to the lyzenga method. It is expected that the substrate analysis strengthens the study of water quality as well as an initial study site of shipwreck objects or marine archeology of shipwrecks as one of the marine tourism destinations. Moreover, the existence of shipwreck sites and the beauty of the waterbed substrate, especially coral reefs, are an attraction.

The analysis of the mapping shallow sea bottom habitats seabed substrate image showed the presence of coastal ecosystems such as coral reefs and seagrass near small islands. The shallow waters enable the metabolic processes of coral and seagrass biota especially for photosynthesis to take place. Furthermore, the condition of the waterbed substrate at the Poso shipwreck location was observed to be close to the live coral reef ecosystem. Towards the mainland of the island, there are seagrass, sand, and a few dead corals. The location of the Tabularasa shipwreck was close to the waterbed substrate of live and dead coral with a few seagrass ecosystems. Furthermore, the existence of the Papatheo shipwreck is far from the small island, and the waterbed substrate was not identified.

\subsection{Historical Shipwreck Sites as Marine Ecotourism Destinations}

The shipwreck site is one of the cultural or archaeological heritage objects whose existence can be a unique attraction. The ongoing bioecological process enables the attachment of living biota (biofouling) to a hard substrate (shipwreck). The process of sticking (fouling) on aircraft wrecks can prevent and reduce the possibility of corrosion. Furthermore, the overall submergence of the Papatheo, Poso, and Tabularasa shipwrecks becomes a place for biota to attach. The attached biota will coat the shipwreck after going through various attachment processes ranging from micro to macro fouling [15] in form of various types of coral. Indirectly, it will be protected and aesthetically become a separate diving tourism area with the presence of coral reefs which form a shipwreck (see: Fig. 2). Examples include the beauty of shipwrecks in the Natuna Sea Island waters, one of which is known as the Tea Ship Site in Karang Panjang Waters, Natuna [9-11]. The Djadayay ship, which is a legacy from Soekarno, has become one of the diving spots in Natuna Waters [10] as well as the popular Liberty shipwreck at Tulamben in Bali [11].

\subsection{Eutrophication and marine ecotourism shipwreck}

The high value of nitrate in measurements at the site of the sinking of the shipwreck indicates the influence of soil waste carried by the river that empties into Jakarta Bay. This is indicated by the frequent occurrence of algal blooms in Jakarta Bay, generally during the transition season [12]. The impact that occurs with nutrient enrichment on marine ecotourism sites sinking ships can cause turbidity as well as the death of biota attached to the ship as one of the attractions of diving such as coral biota and reef fish. It is known that at the location of this research, sunken shipwrecks can be used as diving objects but also as FADs for fish and other biota (see: Fig. 8).

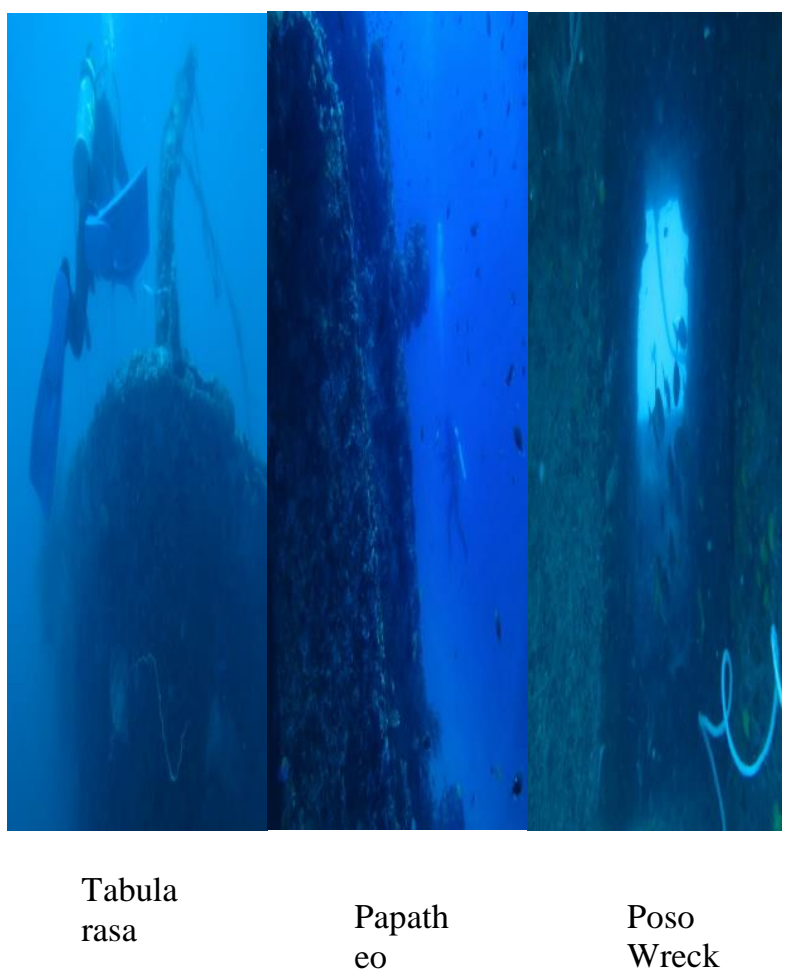

Figure 8. The Shipwreck at the research site

\section{Conclusion}

From the analysis of the water quality based on both images and direct measurements, the condition of the waters is still appropriate with quality standards and supports the growth of marine biota such as coral reefs. The relationship between water quality identification and the sustainability of archaeological sites is indicated by the value of water quality which still supports the existence of the Papatheo, Poso, and Tabularasa shipswreck sites as one of the archaeological site-based marines with diving tourism. However, further studies are required on the carrying capacity of the site as a marine tourism destination (dive spot) and monitoring water quality regularly to enhance the sustainability and maintenance of natural resources.

\section{Acknowledgement}

All authors are major contributors in this research study. This research was funded of LPDP and Marine research center, non tax income annual research funding year 2020. We thanks to for our team in Marine Research Center, Research Institute for ornamental fish culture and The National Research Center for Archaeology, Ministry of education, Culture Research and Technology 


\section{References}

1. M. Made, Kompas.Com (2010).

2. L. Supriatna, J. Supriatna, R. H. Koetsoer, and N. D. Takarina, AIP Conference Proceedings 1729, 020079 (2016).

3. (2004).

4. E. Edwar and J. M. Manik, Kandungan Zat Hara Fosfat Di Teluk Ambon Pada Musim Timur Dan Musim Barat (Teluk Ambon, Biologi, Perikanan, Oseanografi dan Geologi, 1987).

5. H. S. Sanusi, Proses Fisik Kimia Dan Interaksinya Dengan Lingkungan (2006).

6. M. B. Pescod, Nvironmental Indices Theory and Practise. Ann Arbour Science Inc (Michigan, 1987).

7. H. Effendi, Telaah Kualitas Air Bagi Pengelolaan Sumberdaya Dan Lingkungan Perairan (Bogor Agricultural University (IPB), Bogor, 2003).

8. H. P. Hutagalung and D. R. Setiapermana, in Puslitbang Oseanologi (LIPI, 1997).

9. I. Dillenia and R. A. Troa, Jurnal Kelautan Nasional 11, 11 (2016).

10. S. Adhityatama and P. H. Sulistyarto, Jurnal Segara 14, 127 (2018).

11. N. N. H. Ridwan, Jurnal Akreologi Bawah Air 7, (2013).

12. Pusat Penelitian Oseanografi LIPI, 5 Dekade LIPI Di Teluk Jakarta-Review Penelitian Oseanografi Di Teluk Jakarta 1970-2015 (LIPI, 2017). 